\title{
CRISP (crayfish and rice integrated system of production): 2. Modelling crayfish (Procambarus clarkii) population dynamics
}

\author{
P.M. Anastácio ${ }^{a, *}$, S.N. Nielsen ${ }^{b}$, J.C. Marques ${ }^{\mathrm{c}}$ \\ a IMAR, Department of Ecology, University of Évora, Apartado 94, 7001 Évora codex, Portugal \\ ${ }^{\mathrm{b}}$ Royal School of Pharmacy, Environmental Chemistry, Universitetsparken 2, DK2100 Copenhagen, Denmark \\ ${ }^{\mathrm{c}}$ IMAR, Department of Zoology, University of Coimbra, 3000 Coimbra, Portugal
}

Accepted 12 October 1998

\begin{abstract}
An ecological sub-model of crayfish (Procambarus clarkii) population dynamics is presented for integration into the CRISP (crayfish and rice integrated system of production) series of models. The present structure is directed towards simulation of crayfish population responses under different human interventions, namely different capture rates. The crayfish population was subdivided into seven age classes of 80 days, each one constituting a state variable. The increase in weight for each 80-day period was considered dependent on the temperature, the oxygen level and the water level. Mortality was assumed to be dependent on the dry weight of the crayfish and regulated by the total crayfish biomass. Food, water and oxygen content of the water were considered to be non limiting. Total crayfish biomass and total wet weight of crayfish captures were very sensitive to both the temperature for maximum growth and the mortality rates. Our most optimistic simulation, with a $50 \%$ decrease in the mortality rates, resulted in a fourfold increase in captures, from 230 to $917 \mathrm{~kg} \mathrm{ha}^{-1}$ per year. Without capture, a value of $121 \mathrm{~kg} \mathrm{ha}^{-1} \mathrm{was}$ simulated for the average crayfish biomass, which is close to the $124 \mathrm{~kg} \mathrm{ha}^{-1}$ obtained with crayfish capture. Our simulated average crayfish biomass was approximately $120 \mathrm{~kg} \mathrm{ha}^{-1}$ in a natural situation, which lies inside the reported ranges from areas at approximately the same latitude. (C) 1999 Elsevier Science B.V. All rights reserved.
\end{abstract}

Keywords: Crayfish; Procambarus; Model; Population dynamics; Integrated production

\section{Introduction}

The Louisiana Red swamp crayfish, Procambarus clarkii, is an exotic species in Spain and

\footnotetext{
* Corresponding author. Tel.: + 351-266-745385; fax: + 351-266-709498.

E-mail address: anast@evunix.uevora.pt (P.M. Anastácio)
}

Portugal. In both countries, soon after its introduction, crayfish populations increased without control, invading most of the rice fields and wetland areas (Correia, 1993). To prevent damage to rice crops farmers have tried to get rid of crayfish by means of xenobiotic chemicals. Unfortunately, in environmental terms, this was not the wisest decision. A better solution is the use of crayfish as 
a food resource, which would control the size of crayfish populations, with a simultaneous socioeconomical profit (Chien and Avault, 1979; Huner, 1988; Huner et al., 1992; Caño and Ocete, 1994; Huner, 1995).

Three ecological engineering methods have been proposed in order to control crayfish populations in the Lower Mondego river valley (Portugal): (1) harvest of crayfish; (2) use of a non harmful surfactant to decrease the metabolic rate of the crayfish through the control of the gas exchange in the gills; and (3) a combination of (1) and (2). So far the surfactant formulations tested in order to implement solutions (2) and (3) were ineffective when implemented in the field (Anastácio et al., in press). This fact leaves us with the necessity to further explore the first possibility. The aim of this paper is to present an ecological sub-model for crayfish population dynamics.

\section{Study site}

The lower Mondego river valley is located in the central region of Portugal $\left(40^{\circ} 10^{\prime} \mathrm{N}, 8^{\circ} 41^{\prime}\right.$ $\mathrm{W})$. Average temperature of the air is $15.5^{\circ} \mathrm{C}$ (average of 30 years) and yearly precipitation ranges from 800 to $1190 \mathrm{~mm}$ (Ferreira, 1991). The valley consists of approximately 15000 ha and the main agricultural production is rice, which occupies about $60 \%$ of the valley. Non cultivated areas, such as swamps, are usually located in the perimeter of the valley and exhibit a flourishing fauna and flora. Drainage channels, which are widespread across the whole valley, also constitute a biological reservoir. The above mentioned crayfish, $P$. clarkii has been detected in this region since 1984, and is considered by farmers as the cause of substantial damage to local rice production.

\section{Conceptualization of the model}

To accomplish the purposes of the model in a simple and direct way, the number of state variables was reduced to the minimum possible. The crayfish population was subdivided into seven age classes, each one constituting a state variable (Fig. 1). The structure is visually similar to previous models (Anastácio et al., 1993, 1995) but size classes were replaced by age classes. The classes account for differences in mortality rates (Huner, 1978), as well as differences in the fertility of the females (Suko, 1960). Moreover, only the biggest crayfish sizes are harvested, mostly because small

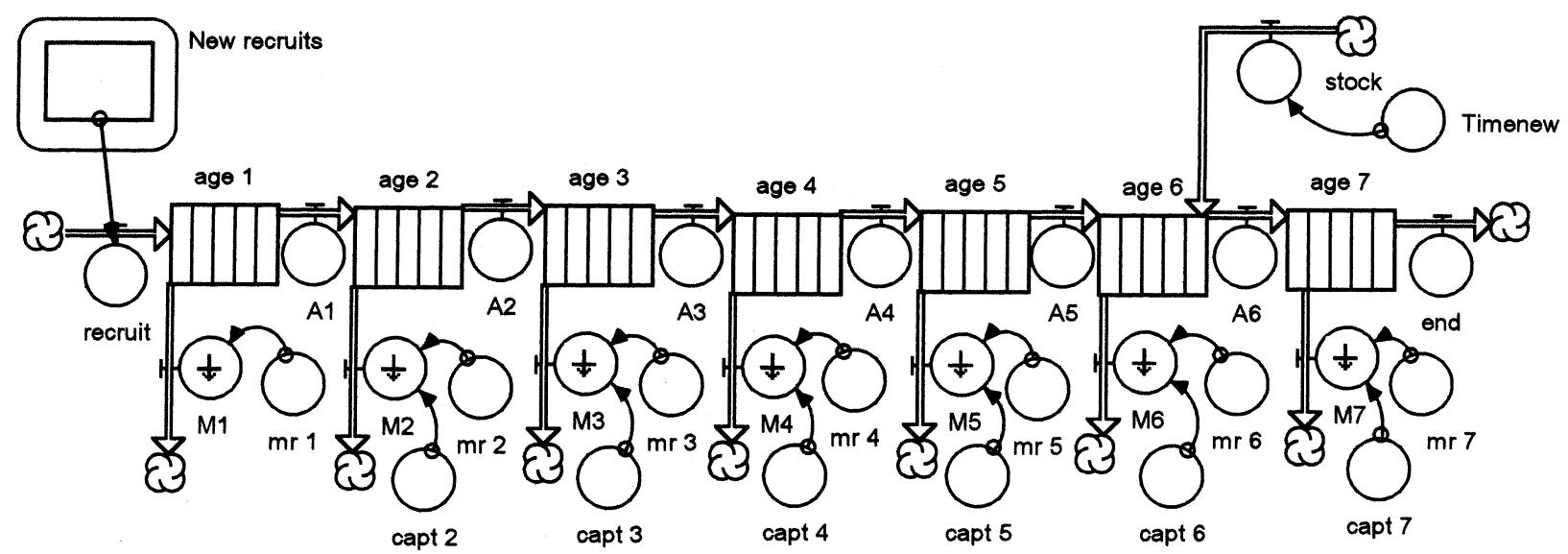

Fig. 1. Conceptual diagram of the model for Stella software: A1-A6, crayfish aging; age1 to age7-80 days age classes; recruit, recruitment of newly born crayfish; M1-M7, total mortality of each age class; capt2-capt7, capture rates for each age class; mr1-mr7, natural mortality rates for each age class; end, individuals reaching maximum life duration; stock, possible linking point for stocking crayfish; timenew, function cycling time of the year. 


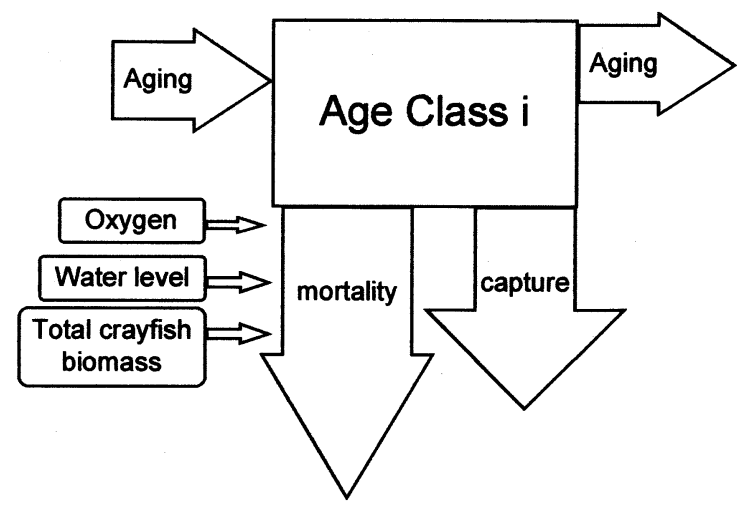

Fig. 2. The basic unit of the model — one age class — and the processes influencing the number of individuals in it.

crayfish have little commercial value. The capture periods can be changed or completely eliminated in order to optimize results. The percentage of crayfish captured is also variable depending on the needs, prices etc.

\section{Model structure}

The basic unit of the model is a age class (Fig. 2). Each crayfish entering an age class takes 80 days to reach the next one. After a period of $7 \times 80$ days ( 1.53 years) crayfish are considered to have reached the maximum life duration i.e. most of them will die after the reproductive period (Penn, 1943). The probability of crayfish dying or being harvested is dependent on the average weight of the age class, which is calculated in a separate module. Recruitment happens during a period of the year (end of September and October), with the number of spawning females increasing to a maximum at a rate of $0.0001 \mathrm{day}^{-1}$ and then decreasing abruptly.

The weight of the crayfish was calculated for each 80-day period. The result is a series of values at each simulation time step in which we have the weights of crayfish with $0,80,160,240,320,400$, 480 and 560 days. These weights are the values for crayfish entering and leaving each age class. Consequently it is possible to make an estimate of the average weight inside each age class by determining the average of the weight of the animals entering and leaving the class.
The increase in weight for each 80-day period was considered dependent on the temperature, the oxygen and the water level. During the dry periods, crayfish retreat to burrows (Huner, 1988; Correia and Ferreira, 1995). Judging from the low frequency at which crayfish feed once inside the burrows (Ilhéu, 1995) and from the potentially adverse environmental conditions, it was assumed that growth was arrested. Oxygen also plays an important role in growth, being one of the factors most frequently referred to as being important for crayfish production (Huner, 1988). The difference in relation to other aquacultural species, such as most fish, is the crayfish ability to survive at low oxygen concentrations, and even the possibility to obtain oxygen from the air (McMahon and Stuart, 1995). These are resources used only in extreme situations and for the model it was considered that growth is negligible if the oxygen was lower than 2 ppm (Araujo and Romaire, 1989 in Lawson et al., 1995).

\section{Equations}

Stella $^{\circledR}$ (version II 3.0.7) was used as software to run the model, and a detailed explanation for the major processes is presented.

\subsection{Growth}

Crayfish weight may be predicted by a modified Von Bertalanffy equation (Gaschutz et al., 1980) previously determined for crayfish of the same area (Anastácio and Marques, 1995).

$\left.L_{t}=L_{\infty}\left\{1-e^{-\left[K d\left(t-t_{0}\right)+C \frac{K d}{2 \pi} \sin 2 \pi\left(t-t_{s}\right)\right.}\right]\right\}^{(1 / d)}$

$L_{t}$ is the length of the organism at a given moment $t ; L_{\infty}$ is the maximum possible length of the organism; $t$ is the given instant; $t_{0}$ is the instant when the organism would have a length $=0 ; t_{\mathrm{s}}$ is the time interval between growth start (when $t=$ 0 ) and the first growth oscillation; growth is expressed by a sin curve with a 1 year period; $K$ is the intrinsic growth rate; $C$ is the parameter with values ranging from 0 to 1 (dependent on the magnitude of the seasonal oscillations in the 
growth rate); $d$ is the parameter that expresses metabolic deviations from Von Bertalanffy's $2 / 3$ rule (the metabolism of an organism is proportional to his weight by a $2 / 3$ power).

The previous equation for the growth in length is a modified and nondifferential approach to the following equation:

$\frac{d_{w}}{d_{t}}=h \times D W^{d}-k \times D W^{m}$

with $d_{w} / d_{t}$ as the instantaneous growth rate; $h \times$ $D W^{d}$ and $k \times D W^{m}$ as the anabolism and catabolism, respectively. Von Bertalanffy (1957) used values of $d=2 / 3$ and $m=1$, which are the recommended standard values for a simple approach to the problem. The output of values of the equation for the length were transformed to dry weights and the daily increase in dry weight was determined and used to fit the equation for the daily increase in the dry weight:

$\frac{d_{w}}{d_{t}}=0.018532 \times D W^{2 / 3}-0.005536 \times D W$

Having a series of values (Fig. 3), $W 1-W 7$, corresponding to the weights after each 80 day period (age class) it is possible to calculate the dry weight by keeping track of the value of the previous $W, 80$ days ago:

$$
\begin{aligned}
W_{i}= & W(i-1)_{(-80)}+T_{\mathrm{eff}} \times \text { days } \\
& \times(0.018532 \times W(i-1))_{(-80)}^{(2 / 3)}-0.005536 \\
& \left.\times W(i-1)_{(-80)}\right)
\end{aligned}
$$

where $W_{i}$, dry weight at the end of age class $I$; $W(i-1)_{(-80)}$, dry weight at the end of age class $i-1 ; T_{\text {eff }}$, temperature regulator for growth, de-

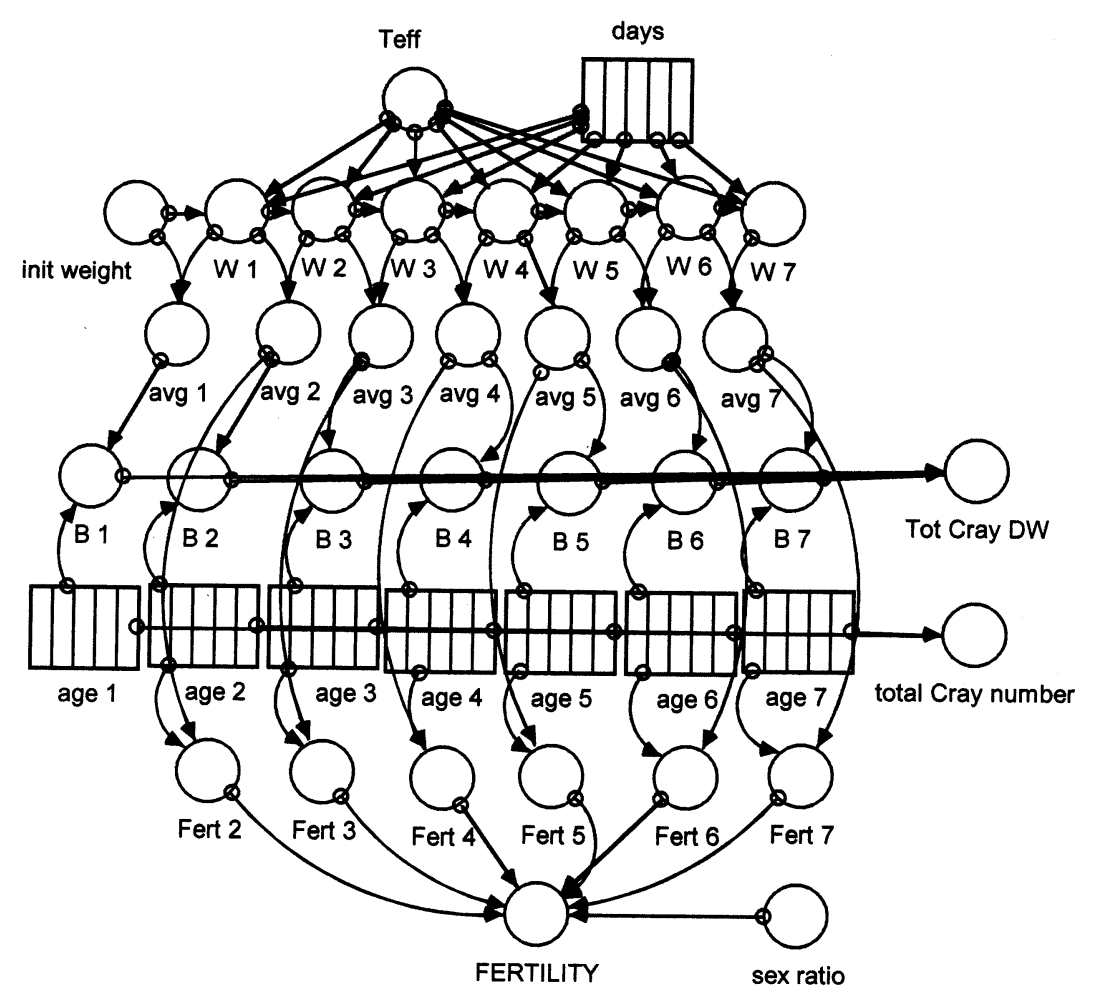

Fig. 3. Stella diagram of the module for calculating the dry weight in each age class: $T_{\text {eff }}$, regulator function dependent on the temperature; days, number of the previous 80 days in which conditions were favorable for growth; initial weight, initial crayfish weight; W1-W7, successive crayfish weights for each 80 days period; avg1-avg7, average crayfish dry weights for each age class; B1-B7, total crayfish dry weights in each age class; tot Cray $D W$, total crayfish biomass in dry weight; age1-age7, number of animals in each age class; total cray number, total number of crayfish; Fert2-Fert7, fertility of each age class. 
pendent on the average temperature during growth; days, number of the previous 80 days in which growth was possible.

The temperature regulator for growth, $T_{\text {eff }}$ was calculated with the aid of an equation from Jørgensen (1976) and Jørgensen et al. (1978):

$f_{(T)}=e^{-2.3 \times\left|\frac{T-T_{\mathrm{opt}}}{T_{\mathrm{opt}}-T_{\min }}\right|}$

in which $T$ is the temperature in ${ }^{\circ} \mathrm{C}, T_{\mathrm{opt}}$ is the temperature for maximum growth, and $T_{\min }$ is the minimum temperature for growth. The growth in the studied region is relatively slow when compared to other places (Anastácio and Marques, 1995). To account for this fact, we have multiplied Jørgensen's formula by four in order to obtain a regulation factor of one at approximately $15^{\circ} \mathrm{C}$. Maximum growth rates can be several times superior to the one determined for the region (see Table 4 in Anastácio and Marques, 1995).

\subsection{Mortality}

It is generally accepted that crayfish (Procambarus clarkii) mortality rates decrease as crayfish grow (e.g. Huner, 1978). In our case, mortality was assumed to be dependent on the dry weight of the crayfish. A negative exponential function was used to describe the dependency:

$m r_{i}=f_{(D W)}=\max m r \times e^{(b \times D W)}$

in which $m r_{i}$ is the mortality rate for crayfish with a dry weight $i$; $\max m \mathrm{r}$ is the maximum mortality rate (mortality of the newly born); $b$ is a constant with a negative value; and $D W$ is the dry weight of the crayfish.

The value of the constant $b$ may be calculated from the equation:

$b=\frac{\ln \left(\frac{\min m r}{\max m r}\right)}{\max D W}$

in which the new variables are: $\min m r$, the minimum mortality rate (the mortality at the maximum dry weight); and $\max D W$, the maximum crayfish dry weight.

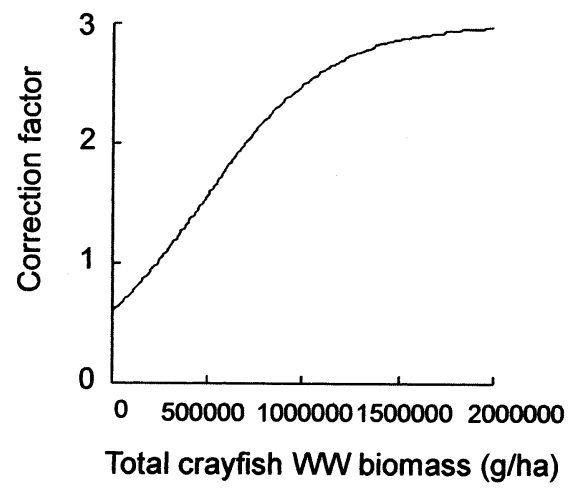

Fig. 4. Graphical representation of the function regulating crayfish mortality. $W W$, wet weight.

Mortality was also considered dependent on the total crayfish biomass. An additional regulator was applied, with values ranging from approximately 0.5 to 3 depending on the biomass at the time. The equation describes a sigmoid curve (Fig. 4):

$f_{\text {(Tot_WW }}=\frac{3}{1+e^{\left(1.38629-0.03 \times \frac{\text { Tot_WW }}{10000}\right)}}$

with Tot_ $W W$ representing the total crayfish wet weight $\left(\mathrm{g} \mathrm{ha}^{-1}\right)$.

Mortality is described by a function of crayfish dry weight $f_{(D W)}$ multiplied by a regulator function $f_{\text {(Tot } W W \text { ) }}$ (dependent on the total crayfish biomass) to which we sum a function for events causing high mortalities $f_{\text {(oxygen, water level) }}$ (such as draught and very low dissolved oxygen concentrations):

$f_{(D W)} \times f_{\text {(Tot_WW }-W}+f_{\text {(oxygen, water level) }}$

\subsection{Fertility}

Fertility is known to depend on the size of the crayfish (Penn, 1943; Suko, 1960; Correia, 1995; Noblitt et al., 1995) and equations relating body measurements to pleopod egg counts are available in the literature. From Noblitt et al. (1995) we have the relation $\mathrm{EGGS}=20.5 \times$ CEF - 573.5; and from Correia (1995) we have the relation $\mathrm{EGGS}=21.679 \times \mathrm{CEF}-475.731$. 
The latter was chosen due to the geographical vicinity. In both equations, EGGS are the pleopod egg counts per crayfish and CEF is the Cefalothorax length in $\mathrm{mm}$.

As the basic structure of the model operates with crayfish dry weight (g), conversion equations were used: (i) $\mathrm{CEF}=0.149355+1.20916 \times$ POCL; with POCL as the post orbital carapace length (Adão, 1991); and (ii) POCL $=\left(10^{1.09555} \times\right.$ $D W)^{(1 / 3.07156)}$, with $D W$ meaning dry weight (adapted from Anastácio and Marques, 1995).

The resulting equation is:

$\mathrm{EGGS}=-443.352+595.934 D W^{0.325567}$

valid for animals above the size at maturity here considered to be $3 \mathrm{~g}$.

For the conversion of dry weight $(D W)$ to wet (live) weight $(W W)$ the following equation was used (Anastácio, 1993):

$W W=5.28607 \times D W^{0.937422}$

\section{Forcing functions}

Temperature was simulated with the aid of a internal graphical device of the software. Monthly averages of the air temperature taken from 30 years data were used as input values and converted to water temperatures. The equation used was: Water_temperature $=1.987686+1.07060653$ $\times$ Air_temperature and it will be explained in a subsequent paper of the CRISP series (Anastácio et al., in press).

\section{Parameters}

If some of the parameter values are unknown, estimation can be made automatically by appropriate software (Jørgensen, 1994) or by implementing numerical optimization procedures by means of programming (e.g. flexible polyhedron search, Marsili-Libelli, 1992). Due to the nature of the Stella software, automatic calibration was not performed. Instead, we performed trial and error calibrations.

All the parameters are easily changeable in order to make the model adaptable to local conditions. Table 1 summarizes the values used, but the model is based mostly on data from Anastácio and Marques (1995). Parameters regarding mortality of the oldest age classes, as well as the number of females spawning were obtained from field observations from Baptista et al. (1994), and from available literature (Table 2).

The equation used for growth was determined for an area with an average temperature of $15^{\circ} \mathrm{C}$. If we use this to consider that growth is temperature dependent, a temperature dependency function must be added, in which we have a minimum, an optimum and a maximum temperature for growth. Optimum temperatures for crayfish production have been referenced by many authors (Table 3). For the model, optimum temperature was considered as the temperature at which maximum growth would occur, and is not necessarily the optimum temperature for crayfish production. In fact, at high temperatures crayfish

Table 1

Parameter values used in the model

\begin{tabular}{|c|c|c|c|}
\hline Parameter & Description & Value & Reference \\
\hline$T_{\text {opt }}$ & Temperature for maximum growth & $30^{\circ} \mathrm{C}$ & see Table 3 \\
\hline Sex ratio & Proportion of females in the population & 0.8 & $\begin{array}{l}\text { Anastácio and Marques, } \\
1995\end{array}$ \\
\hline Initial weight & Initial crayfish dry weight & $0.00096 \mathrm{~g}$ & $\begin{array}{l}\text { Anastácio and Marques, } \\
1995\end{array}$ \\
\hline Capture end & End of crayfish captures expressed as the day of the year & 70 & Calibration \\
\hline $\begin{array}{l}\text { Minimum capture } \\
\quad D W\end{array}$ & Minimum wet weight of the crayfish captured & $20 \mathrm{~g}$ & Calibration \\
\hline
\end{tabular}


Table 2

Literature values for crayfish (Procambarus clarkii) mortality rates

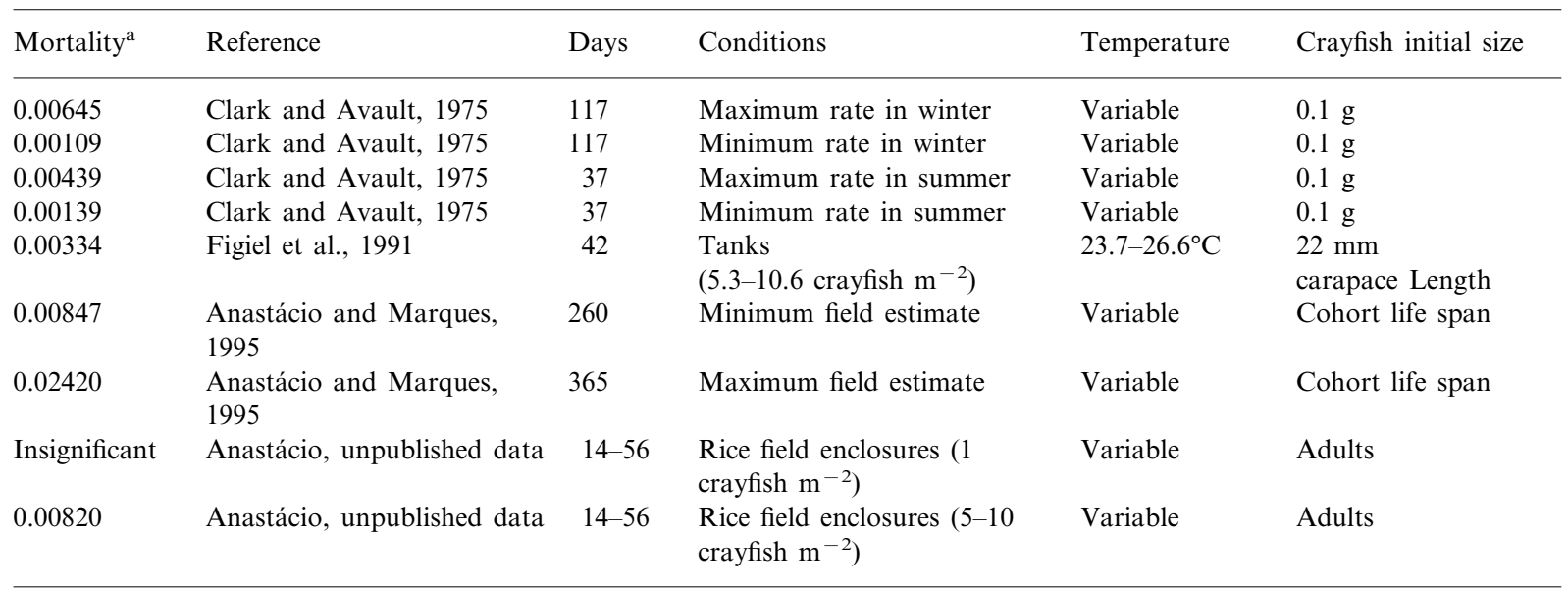

a All the original data were converted to daily rates.

may have a very high growth rate, but also a higher mortality rate (Chien and Avault, 1983). This is the reason why our temperature for maximum growth was considered a little higher than the usually referred optimum temperature.

At this point, both the water and oxygen content of the water were considered to be non limiting; i.e. with a constant and reasonably high value. After coupling with other sub-models they will operate as state variables.

\section{Sensitivity analysis}

According to Jørgensen (1994) the purpose of a sensitivity analysis is to provide a measure of the sensitivity of parameters, forcing functions or sub models to the most important state variables in a model. This will provide an additional knowledge of the properties of the model.

Frequently sensitivity analysis is conducted independently for each parameter but this procedure can be misleading (Elston, 1992). For the simplicity of the final form of the paper, no results of a combined sensitivity analysis of several parameters are presented. Nevertheless such analysis was performed (manually) in the early stages of the model construction in order to obtain a correct calibration.

Sensitivity analysis were performed with \pm 10 and $\pm 50 \%$ oscillations in the parameter values whenever biologically reasonable. As an example, for the female proportion (0.8), there is no sense in making a sensitivity check for a variation of $+50 \%$ in the parameter value.

The most important state variables in the model were considered to be the total crayfish $W W$ biomass and the total $W W$ of crayfish captures. They were used to test the model sensitivity to several parameters. Two main situations were simulated: with and without crayfish captures. Sensitivity analysis on the two state variables were performed according to these two situations. Three tables were constructed, namely of sensitivity of total crayfish biomass with capture (Table 4) and without capture (Table 5) and sensitivity of total crayfish captures (Table 6).

Results show that the model is very sensitive to both the optimum temperature (i.e. temperature for maximum growth) and the mortality rates. Although easily controlled by the farmers, the start and end of the crayfish capture season does not play a fundamental role in the model outputs. 


\section{Simulation results}

Simulation results were compared with field data on a non harvested population from a drainage channel, obtained by Anastácio and Marques (1995) (Fig. 5). A comparison of the observed and simulated data show a temporal match in the peaks of crayfish biomass. Nevertheless, the model outputs are within a narrower range than the field data. Simulations were also performed for 3 year periods, with and without crayfish captures (Fig. 6). Crayfish capture induced a temporal shift in the peaks of maximum crayfish biomass, from late Spring to late Autumn.

The simulated values of crayfish captures, under the modeled constraints, are of about $230 \mathrm{~kg}$ $\mathrm{ha}^{-1}$ per year. By reducing the mortality rates to $50 \%$ of the actual values, maximum captures of crayfish reach the value of $917 \mathrm{~kg} \mathrm{ha}^{-1}$ per year. Without capture, a value of $121 \mathrm{~kg} \mathrm{ha}^{-1}$ was obtained for the average crayfish biomass, which is similar to the $124 \mathrm{~kg} \mathrm{ha}^{-1}$ obtained with crayfish capture.

\section{Discussion/future developments}

Momot (1984), refers to three main mechanisms regulating the responses of crayfish to alteration of the population structure: (1) shortening of the life span by increased growth; (2) changes in fecundity rates; and (3) shifts in age specific mortality rates. Nevertheless, most changes in year to year cohort production are caused by adjustments in the mortality rates. The assumption that mortality is the most important process for self regulation is the focal point of the present model.

Self regulation by density dependence has been described for several crayfish populations (Momot, 1977; Momot and Gowing, 1977a,b; Momot et al., 1978). In the model, self regulation is attained by total crayfish biomass in the system, which is closely associated with density. The advantage is that biomass may have a more profound ecological meaning than density. Actually, several rates, such as of oxygen or food consumption, are more easily derived from biomass.

Some criticisms may arise from the fact that although proven for P. clarkii (Lutz and Wolters,

Table 3

Literature values for optimum, maximum and minimum temperatures for crayfish (Procambarus clarkii $)^{\mathrm{a}}$

\begin{tabular}{|c|c|c|c|c|}
\hline Author & $\begin{array}{l}\text { Optimum } \\
\text { temperature }\end{array}$ & $\begin{array}{l}\text { Maximum } \\
\text { temperature }\end{array}$ & $\begin{array}{l}\text { Minimum } \\
\text { temperature }\end{array}$ & Notes \\
\hline $\begin{array}{l}\text { Taylor, } 1984 \text { in Es- } \\
\text { pina et al., } 1993\end{array}$ & 21.96 & & & Crayfish acclimated to $20-21^{\circ} \mathrm{C}$ \\
\hline $\begin{array}{l}\text { Provenzano and } \\
\quad \text { Handwerker, } 1995\end{array}$ & & 30 & & $\begin{array}{l}\text { Threshold temperature for detrimental effects } \\
\text { on survival and egg laying }\end{array}$ \\
\hline Suko, 1956 & & & 5 & Embryonic development \\
\hline $\begin{array}{l}\text { Culley and Duobinis- } \\
\text { Gray, } 1990\end{array}$ & 27 & $>32$ & & $\begin{array}{l}\text { Values recommended for soft crayfish produc- } \\
\text { tion }\end{array}$ \\
\hline
\end{tabular}

${ }^{\text {a }}$ All the temperatures are in ${ }^{\circ} \mathrm{C}$. 
Table 4

Results of the sensitivity analysis on total crayfish biomass, in simulations with crayfish capture

\begin{tabular}{|c|c|c|}
\hline Parameter tested & Value & Sensitivity \\
\hline Capture rate (proportion/day) & $\begin{array}{l}0.1 \\
0.18 \\
0.22 \\
0.3\end{array}$ & $\begin{array}{r}-0.0018 \\
0.0042 \\
-0.0026 \\
-0.0043\end{array}$ \\
\hline End of season (day of the year) & $\begin{array}{r}120 \\
35 \\
63 \\
77\end{array}$ & $\begin{array}{r}0.0043 \\
-0.0028 \\
-0.0257 \\
0.0193\end{array}$ \\
\hline Mortality multiplier (scalar) & $\begin{array}{l}0.5 \\
0.9 \\
1.1 \\
1.5\end{array}$ & $\begin{array}{r}5.9051 \\
3.5274 \\
-2.8250 \\
-1.6320\end{array}$ \\
\hline Minimum weight (g) & $\begin{array}{l}10 \\
18 \\
22 \\
30\end{array}$ & $\begin{array}{r}-0.0008 \\
0.0000 \\
0.0000 \\
-0.0093\end{array}$ \\
\hline $\begin{array}{l}\text { Start of season (day of the } \\
\text { year) }\end{array}$ & $\begin{array}{r}11 \\
15 \\
5 \\
9\end{array}$ & $\begin{array}{r}0.0324 \\
0.0153 \\
-0.0439 \\
-0.0352\end{array}$ \\
\hline Female proportion & $\begin{array}{l}0.72 \\
0.88\end{array}$ & $\begin{array}{r}-0.4994 \\
0.4615\end{array}$ \\
\hline Optimum temperature $\left({ }^{\circ} \mathrm{C}\right)$ & $\begin{array}{l}15 \\
27 \\
33 \\
45\end{array}$ & $\begin{array}{r}-0.6572 \\
5.4403 \\
-5.0915 \\
-1.6841\end{array}$ \\
\hline
\end{tabular}

1986; McClain, 1995a,b), the negative influence of density on growth has not been taken into account. In reality, the relation will become important only at high crayfish biomasses (over $1235 \mathrm{~kg}$ $\mathrm{ha}^{-1}$ ) (McClain, 1995c). Once more, the role of biomass is emphasized.

Calibration of the model was performed with data from a natural population. It is expected that in rice fields the numbers of predators will be lower. The low water levels $(10 \mathrm{~cm})$ and instability of the system (wet/dry) make it difficult for fish to attain stable populations. Moreover, although the density of predatory birds (mainly Ardeidae) can be very high in natural areas in the region (Anastácio and Amaro, 1989, 1992), they are present but usually less frequent in the rice fields.
This decrease in predators together with adequate management strategies, should decrease mortality rates. As the model is extremely sensitive to changes in these rates, crayfish production in rice fields could be considerably higher than the simulated values of $230 \mathrm{~kg} \mathrm{ha}^{-1}$ per year.

Normal production values for swamp and marsh ponds range from 200 to $600 \mathrm{~kg} \mathrm{ha}^{-1}$ per year, but in rice ponds values are known to normally range from 1000 to $2000 \mathrm{~kg} \mathrm{ha}^{-1}$ per year (Huner, 1988). Our most optimistic simulation, with a simulation of a $50 \%$ decrease in the mortality rates, resulted in a four fold increase in captures to around $917 \mathrm{~kg} \mathrm{ha}^{-1}$ per year. This would provide a considerable additional profit for a farmer.

Biomasses for naturally occurring crayfish populations in California rice fields ranged from 1.4 to $204 \mathrm{~kg} \mathrm{ha}^{-1}$ (Sommer and Goldman, 1983). Correia (1995) found average crayfish biomasses of $5.65 \mathrm{~kg} \mathrm{ha}^{-1}$ in a Portuguese rice field, but average values ranged from 2.52 to $316.8 \mathrm{~kg} \mathrm{ha}^{-1}$ depending on the habitat studied. In certain habitats (freshwater marshes) maximum values reached $2200 \mathrm{~kg} \mathrm{ha}^{-1}$. Our simulated average biomass was of approximately $120 \mathrm{~kg} \mathrm{ha}^{-1}$ in a natural situation, which lies inside the reported ranges from areas at approximately the same latitude. Although Fig. 5 may indicate some differences in the simulated and observed values one must take into account that the area sampled (a drainage channel) is not exactly equal to the area

Table 5

Results of the sensitivity analysis on total crayfish biomass, in simulations without crayfish capture

\begin{tabular}{lcc}
\hline Parameter tested & Value & Sensitivity \\
\hline Mortality multiplier (scalar) & 0.5 & 4.9474 \\
& 0.9 & 2.9562 \\
& 1.1 & -2.4013 \\
Female proportion & 1.5 & -1.4445 \\
& 0.72 & -0.3934 \\
Optimum temperature $\left({ }^{\circ} \mathrm{C}\right)$ & 0.88 & 0.3636 \\
& 15 & -0.3843 \\
& 27 & 3.4010 \\
& 33 & -4.5505 \\
& 45 & -1.5664 \\
\hline
\end{tabular}


Table 6

Results of the sensitivity analysis on crayfish capture $(W W)$

\begin{tabular}{|c|c|c|}
\hline Parameter tested & Value & Sensitivity \\
\hline Capture rate (proportion/day) & $\begin{array}{l}0.1 \\
0.18 \\
0.22 \\
0.3\end{array}$ & $\begin{array}{r}-0.1192 \\
-0.0493 \\
0.0300 \\
0.0238\end{array}$ \\
\hline End of season (day of the year) & $\begin{array}{r}120 \\
35 \\
63 \\
77\end{array}$ & $\begin{array}{r}0.1165 \\
-0.8911 \\
-0.3335 \\
0.2856\end{array}$ \\
\hline Mortality multiplier (scalar) & $\begin{array}{l}0.5 \\
0.9 \\
1.1 \\
1.5\end{array}$ & $\begin{array}{r}4.7113 \\
2.8856 \\
-2.3459 \\
-1.4220\end{array}$ \\
\hline Minimum weight (g) & $\begin{array}{l}10 \\
18 \\
22 \\
30\end{array}$ & $\begin{array}{r}-0.2036 \\
0.0000 \\
0.0000 \\
-1.5906\end{array}$ \\
\hline $\begin{array}{l}\text { Start of season (day of the } \\
\text { year) }\end{array}$ & $\begin{array}{r}11 \\
15 \\
5 \\
9\end{array}$ & $\begin{array}{l}-0.0114 \\
-0.0168 \\
-0.0046 \\
-0.0041\end{array}$ \\
\hline Female proportion & $\begin{array}{l}0.72 \\
0.88\end{array}$ & $\begin{array}{r}-0.2398 \\
0.1953\end{array}$ \\
\hline Optimum temperature $\left({ }^{\circ} \mathrm{C}\right)$ & $\begin{array}{l}15 \\
27 \\
33 \\
45\end{array}$ & $\begin{array}{r}-0.2920 \\
4.3177 \\
-5.8504 \\
-1.7059\end{array}$ \\
\hline
\end{tabular}

simulated (a rice field). Actually we believe that the simulation is closer to the reality in the rice field without an efficient control of crayfish populations.

Presently the model is not validated, but this step will be taken after all the sub models of the CRISP series are coupled. Meanwhile it should be regarded as a tool which will improve our understanding of crayfish population dynamics and will also increase our management skills. The structure of the model is directed towards simulation of crayfish population responses under different human interventions. Examples are the hydrological regimes to be used in the rice field or the planning of crayfish capture effort.

Some of the future linking points with the

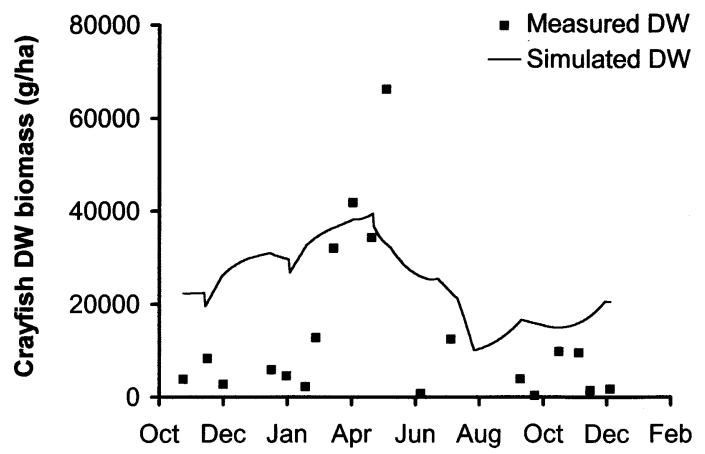

Fig. 5. Comparison of a crayfish biomass (dry weight) simulation without capture and values obtained in nature.

other sub-models, which will have a direct impact on this model, are the water level, the water quality (namely the oxygen concentrations) and the impact of crayfish on plant (mainly rice) and animal communities (macroinvertebrates). The model can be considered as acceptable under the present calibration conditions, but further calibration should be performed when used in conjunction with the other sub-models. As a final remark, it is advisable for future crayfish modelers to be extremely careful in assessing the crayfish mortality rates. Special attention should be given to its relation to age and environmental conditions.

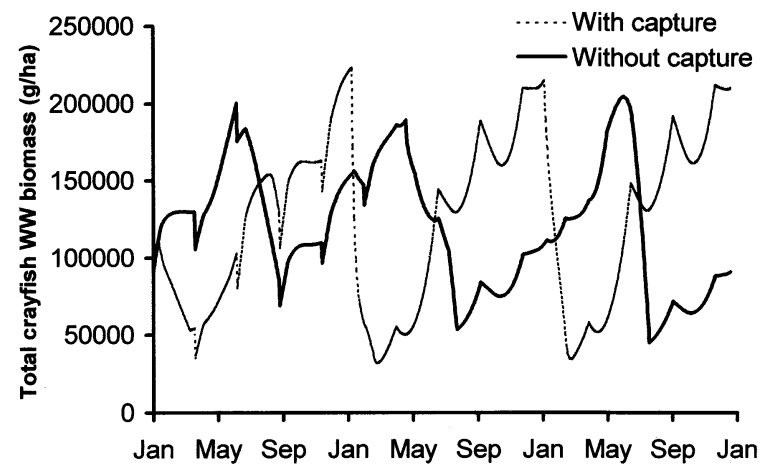

Fig. 6. Comparison of the simulated values of total crayfish biomass, with and without capture. $W W$, wet weight. 


\section{Acknowledgements}

This work was sponsored by the EU in the scope of the R and D project AIR 3-CT-94-2432 and also by JNICT and the PRAXIS XXI Program (Portugal).

\section{References}

Adão, M.H., 1991. Procambarus clarkii (Girard, 1852) (Decapoda, Cambaridae) espécie exótica em portugal. Considerações sobre a ecobiologia e aspectos da sua biologia populacional na barragem de Monte Novo (Alentejo, Portugal). Provas de aptidão pedagógica e scientífica. Universidade de Évora, pp. 134

Anastácio, P.M., 1993. Ciclo biológico e produção do lagostim vermelho da Louisiana (Procambarus clarkii, Girard) na região do baixo Mondego. M.Sc. Thesis. University of Coimbra, Coimbra, Portugal.

Anastácio, P.M., Amaro, P.N., 1989. Breves notas sobre os estudos faunísticos na quinta do taipal. In: Proceedings of the II Congresso das Áreas Protegidas, pp. 259-267.

Anastácio, P.M., Amaro, P.N., 1992. The Ardeidae populations of the Quinta do Taipal marsh (Lower Mondego, Portugal). Airo 3, 13-17.

Anastácio, P.M., Marques, J.C., 1995. Population biology and production of the red swamp crayfish Procambarus clarkii (Girard) in the lower Mondego river valley, Portugal. J. Crustac. Biol. 15 (1), 156-168.

Anastácio, P.M., Nielsen, S.N., Marques, J.C., Jørgensen, S.E., 1993. Rice and crayfish production in the lower mondego river valley: a management model for farmers. In: Proceedings of the International congress on Modelling and Simulation, pp. 1687-1692.

Anastácio, P.M., Nielsen, S.N., Marques, J.C., Jørgensen, S.E., 1995. Integrated production of crayfish and rice: a management model. Ecol. Eng. 4, 199-210.

Baptista, P.A.P., Anastácio, P.M., Marques, J.C., 1994. Adult crayfish (Procambarus clarkii) population structure in the lower Mondego river valley, central Portugal. In: Proceedings of the International congress of ecology. Intecol. IV:266 (Abstract)

Bertalanffy, L.V., 1957. Quantitative laws in metabolism and growth. Q. Rev. Biol. 32 (3), 217-231.

Buckle Ramirez, L.F., Herrera, F.D., Sandoval, F.C., Sevilla, B.B., Rodriguez, M.H., 1994. Diel thermoregulation of the crawfish Procambarus clarkii (Crustacea, Cambarinae). J. Therm. Biol. 19 (6), 419-422.

Caño, E., Ocete, M.E., 1994. Estimación sobre las repercursiones socio-económicas de Procambarus clarkii Girard (Decapoda, Cambaridae) en las marismas del bajo Guadalquivir. Bol. San. Veg. Plagas 20, 653-660.

Chien, Y.H., Avault, J.W., 1983. Effects of flooding dates and type of disposal of rice straw on the initial survival and growth of caged juvenile crayfish, Procambarus clarkii, in ponds. Freshw. Crayfish 5, 344-350.

Chien, Y.H., Avault, J.W., 1979. Double cropping rice, Oryza sativa and red swamp crawfish, Procambarus clarkii. Freshw. Crayfish 4, 263-272.

Clark, D.F., Avault, J.W., 1975. Effects of feeding, fertilization, and vegetation on production of red swamp crayfish, Procambarus clarkii. Freshw. Crayfish 2, 125-138.

Correia, A.M., 1993. Situation de l'acclimatation de l'crevisse rouge des marais Procambarus clarkii au Portugal. L'astacicul. Fr. 35, 2-9.

Correia, A.M., Ferreira, O., 1995. Burrowing behavior of the introduced red swamp crayfish Procambarus clarkii (Decapoda: Cambaridae) in Portugal. J. Crustac. Biol. 15 (2), $248-257$.

Correia, A.M., 1995. Biologia populacional e interacções tróficas de Procambarus clarkii (Crustacea, Decapoda, Cambaridae) no sistema hidrográfico do rio Tejo (Ribatejo, Portugal). PhD. Dissertation. Faculdade de Ciencias. Universidade de Lisboa, Lisboa.

Culley, D.D., Duobinis-Gray, L.F., 1990. A Production Manual. Culture of the Louisiana Soft Crawfish. Louisiana Sea Grant College Program. Center for wetland resources. Louisiana State University.

Elston, D.A., 1992. Sensitivity analysis in the presence of correlated parameter estimates. Ecol. Model. 64, 11-22.

Espina, S., Herrera, F.D., Buckle, L.F., 1993. Preferred and avoided temperatures in the crawfish Procambarus clarkii (Decapoda, Cambaridae). J. Therm. Biol. 18, 35-39.

Ferreira, F.S., 1991. O baixo Mondego sem projecto e com projecto. Semente 3, 26-34.

Figiel, C.R.J.R., Babb, J.G., Payne, J.F., 1991. Population regulation in young of the year crayfish, Procambarus clarkii (Girard, 1852) (Decapoda, Cambaridae). Crustaceana 61, 301-307.

Gaschutz, G., Pauly, D., David, N., 1980. A Versatile Basic Program for Fitting Weight and Seasonally Oscillating Length Growth Data. Pelagic, Demersal and Shellfish Cttes, pp. 23.

Huner, J.V., 1978. Crawfish population dynamics as they affect production in several small, open commercial crawfish ponds in Louisiana. Proc. Ann. Meet. World Maricult. Soc. 9, 619-640.

Huner, J.V., 1988. Procambarus in North America and elsewhere. In: Holdich, D.M. (Ed.), Freshwater Crayfish. Biology, Management and Exploitation. Croom Helm, London, pp. 239-261.

Huner, J.V., 1995. An overview of the status of freshwater crawfish culture. J. Shellfish Res. 14 (2), 539-543.

Huner, J.V., Barr, J.E., 1991. Red Swamp Crawfish: Biology and Exploitation. Louisiana Sea Grant College Program, Baton Rouge, Louisiana.

Huner, J.V., Holdich, D.M., Westman, K., 1992. Crayfish management strategies and management methods in Europe: a summary. Finn. Fish. Res. 14, 157-159.

Ilhéu, M.A., 1995. Lagostim vermelho dos pantanos (Procambarus clarkii, Girard): Ecologia e impacto trófico. Department of Zoology, University of Coimbra, Coimbra. 
Jørgensen, S.E., 1976. A eutrophication model for a lake. Ecol. Model. 2, 147-165.

Jørgensen, S.E., 1994. Fundamentals of Ecological Modelling. Elsevier, Amsterdam.

Jørgensen, S.E., Mejer, H.F., Friis, M., 1978. Examination of a lake model. Ecol. Model. 4, 253-278.

Lawson, T.B., Bankston, J.D., Baker, F.E., Hymel, T.M., Shirley, M.G., 1995. Paddlewheel aerator use in commercial crawfish ponds. Freshw. Crayfish 8, 533-552.

Lutz, C.G., Wolters, W.R., 1986. The effect of five stocking densities on growth and yield of red swamp crawfish Procambarus clarkii. J. World Aquacult. Soc. 17 (1-4), 33-36.

Marsili-Libelli, S., 1992. Parameter estimation of ecological models. Ecol. Model. 62, 233-258.

McClain, W.R., 1995a. Growth of crayfish Procambarus clarkii as a function of density and food resources. J. World Aquacult. Soc. 26 (1), 24-28.

McClain, W.R., 1995b. Investigations of crayfish density and supplemental feeding as factors influencing growth and production of Procambarus clarkii. Freshw. Crayfish 10, 512-520.

McClain, W.R., 1995c. Effects of population density and feeding rate on growth and feed consumption of red swamp crayfish Procambarus clarkii. J. World Aquacult. Soc. 26 (1), 14-23.

McMahon, B.R., Stuart, S.A., 1995. Simulating the crayfish burrow environment: air exposure and recovery in Procambarus clarkii. Freshw. Crayfish 8, 451-461.

Momot, W.T., 1977. Response of the crayfish Orconectes virilis to exploitation. J. Fish. Res. Board Can. 34, 1212-1219.
Momot, W.T., 1984. Crayfish production: a reflection of community energetics. J. Crustac. Biol. 4, 35-54.

Momot, W.T., Gowing, H., 1977a. Results of an experimental fishery on the crayfish Orconectes virilis. J. Fish. Res. Board Can. 34, 2056-2066.

Momot, W.T., Gowing, H., 1977b. Production and population dynamics of the crayfish Orconectes virilis in three Michigan lakes. J. Fish. Res. Board Can. 34, 2041-2055.

Momot, W.T., Gowing, H., Jones, P.D., 1978. The dynamics of crayfish and their role in ecosystems. Am. Midl. Nat. 99, 10-35.

Noblitt, S.B., Payne, J.F., Delong, M., 1995. A comparative study of selected physical aspects of the eggs of the crayfish Procambarus clarkii (Girard, 1852) and P. zonangulus Hobbs and Hobbs, 1990 (Decapoda, Cambaridae). Crustaceana 68 (5), 575-582.

Penn, G.H., 1943. A study of the life history of the Louisiana red crawfish, Cambarus clarkii Girard. Ecology 24, 1-19.

Provenzano, A.J.J., Handwerker, T.S., 1995. Effects of photoperiod on spawning of red swamp crayfish, Procambarus clarkii, at elevated temperature. Freshw. Crayfish 8, 311320 .

Sommer, T.R., Goldman, C.R., 1983. The crayfish Procambarus clarkii from California ricefields. Ecology, problems and potential harvest. Freshw. Crayfish 5, 418-428.

Suko, T., 1956. Studies on the development of the crayfish. iv. The development of winter eggs. Ibid 2, 213-219.

Suko, T., 1960. Studies on the development of the crayfish. vi. The reproductive cycle. Sci. Rept. Saitama Univ. 3B, 7991. 